\title{
Penampilan Agronomi Galur-Galur Padi Sawah Tadah Hujan Toleran Kondisi Anaerob pada Fase Perkecambahan
}

\section{Agronomic Performances of Rainfed Lowland Rice Genotypes Tolerant to Anaerobic Germination}

\author{
Trias Sitaresmi ${ }^{1 *}$, Nita Kartina ${ }^{1}$, Aida Fitri Viva Yuningsih ${ }^{1}$, Indrastuti Apri Rumanti ${ }^{1}$, \\ Nafisah $^{1}$, Untung Susanto ${ }^{1}$, dan Yudhistira Nugraha ${ }^{2}$ \\ ${ }^{1}$ Balai Besar Penelitian Tanaman Padi \\ Jl. Raya 9 Sukamandi, Subang, Jawa Barat 41256, Indonesia \\ ${ }^{2}$ Pusat Penelitian dan Pengembangan Tanaman Pangan \\ Jl. Merdeka 147 Bogor 16111, Indonesia
}

Diterima 17 Januari 2021/Disetujui 21 April 2021

\begin{abstract}
Direct seeding in rainfed lowland areas requires adaptive varieties as well as tolerant to low oxygen levels during germination under flooded condition or anaerobic germination $(A G)$. The research was aimed to evaluate agronomic performances of rice genotypes and evaluate their tolerance to $A G$. Evaluation of rice genotype tolerant to AG was conducted at Indonesian Center for Rice Research's greenhouse in February 2020. The materials were 12 genotypes. Screening AG was carried out by soaking the seeds in $50 \mathrm{~cm}$ of depth water for 10 days. Agronomic performance of genotypes was evaluated in rainfed lowland at Sumedang and Pati during the wet season of 2020. The experiments were arranged in a randomized complete block design with four replications in each location. Based on recovery ability, shoot length, root length, and biomass, we identified that IR 83381-B-B-6-1, IR 129336:11-19-Ski-0-Kn-3 and B14897E-SKI-9-7-2 had better AG tolerance compared with popular check varieties. The field experiment showed the lines were not significantly different for grain yield compared to the check varieties, namely Inpari 30 and Inpari 39. IR 129336:11-19-Ski-0-Kn-3 (5.61 ton ha-1) and B14316E-KA-15 (6.04 ton $\mathrm{ha}^{-1}$ ) had consistently high yield in two locations. These results revealed that IR 83381-B-B-61, IR 129336:11-19-Ski-0-Kn-3 and B14897E-SKI-9-7-2 are recommended for multilocations trials on yield potential and adaptability in order to be released as tolerant varieties to $A G$.
\end{abstract}

Keywords: abiotic stress, anaerobic germination, direct seeding

\section{ABSTRAK}

Budidaya padi di sawah tadah hujan dengan sistem tebar benih langsung memerlukan varietas yang beradaptasi baik pada kondisi ekosistem tersebut dan toleran terhadap tingkat oksigen rendah selama berkecambah atau anaerobic germination $(A G)$. Penelitian bertujuan mengevaluasi penampilan agronomi galur-galur padi dilakukan di sawah tadah hujan, serta toleransinya terhadap kondisi AG. Evaluasi toleransi cekaman kondisi anaerob dilakukan di rumah kaca BB Padi pada bulan Februari 2020. Materi yang digunakan adalah 12 genotipe padi. Penapisan AG dilakukan dengan merendam benih dalam air dengan ketinggian $10 \mathrm{~cm}$ selama 10 hari. Pengujian daya hasil dilakukan di sawah tadah hujan Sumedang dan Pati pada musim hujan 2020. Percobaan disusun menggunakan rancangan kelompok lengkap teracak dengan empat ulangan. Toleransi terhadap kondisi AG dapat diidentifikasi berdasarkan karakter persentase daya pulih, panjang tunas dan akar, dan biomassa. Karakter-karakter tersebut saling berkorelasi nyata, positif, dan kuat. Galur IR 83381-B-B-6-1, IR 129336:11-19-Ski-0-Kn-3 dan B14897E-SKI-9-7-2 memiliki toleransi AG lebih baik daripada Inpari 30 dan Inpari 39. Dari hasil pengujian lapangan, dua galur memiliki rata-rata GKG setara dengan Inpari 30 dan Inpari 39, serta konsisten cukup tinggi yaitu IR 129336:11-19-Ski-0-Kn-3 (5.61 ton ha ${ }^{-1}$ ) dan B14316E-KA-15 (6.04 ton ha d $^{-1}$. Hasil pengujian ini dapat dilanjutkan dengan uji multi lokasi pada galur IR 83381-B-B-6-1, IR 129336:11-19-Ski-0-Kn-3 dan B14897E-SKI-9-7-2 dengan mempertimbangkan daya hasil dan adaptasinya sehingga dapat dilepas menjadi varietas toleran AG.

Kata kunci: cekaman abiotik, perkecambahan anaerob, tebar benih langsung

\footnotetext{
* Penulis untuk korespondensi. e-mail: triassitaresmi@gmail.com
} 


\section{PENDAHULUAN}

Anomali iklim yang saat ini terjadi berdampak terhadap sulitnya memperkirakan intensitas banjir yang melanda pertanaman padi, baik durasi terendamnya tanaman maupun ketinggian permukaan airnya (Nugraha et al., 2013; Yullianida et al., 2014). Secara umum benih tanaman padi akan gagal tumbuh pada kondisi kurang oksigen atau terendam selama beberapa hari, namun beberapa varietas padi dapat menunjukkan toleransi terhadap kondisi anaerob selama perkecambahan (anaerobic germination), dengan cara munculnya koleoptil dan pertumbuhan parsial (Bordoloi et al., 2018). Cekaman kondisi anaerob pada sistem tebar benih langsung (tabela) disebabkan oleh lahan kurang rata atau sistem drainase yang buruk. Pada beberapa daerah tadah hujan seperti di Sulawesi Selatan, petani menggunakan tabela dan melakukan perendaman lahan sedalam 20-30 cm, yang bertujuan untuk menghemat air dan mengatasi kondisi gulma (Tuong et al., 2000; Ismail et al., 2012; Septiningsih, et al., 2013; Chamara et al., 2018). Hal ini mengakibatkan jumlah benih yang harus ditabur bisa mencapai 70-100 $\mathrm{kg} \mathrm{ha}^{-1}$ untuk mengatasi daya tumbuh benih yang rendah (Hamid, 2005). Praktek ini juga dilakukan di beberapa negara maju seperti Australia, Italia dan Amerika (Hill et al., 1991).

Secara umum, padi memberikan respon sensitif terhadap kondisi rendah oksigen selama fase perkecambahan. Studi menunjukkan padi memiliki kemampuan berkecambah dan memanjangkan koleoptil pada kondisi oksigen rendah (hipoksia) dan sangat rendah/tidak ada oksigen (anoksia) (Ismail et al., 2012; Hendawy et al., 2017; Illangakoon et al., 2018). Galur toleran tersebut memiliki aktivitas amilase lebih tinggi untuk merombak karbohidrat yang ada didalam benih (Ismail et al., 2009) dan berhubungan dengan peningkatan A trehalose-6-phosphate phosphatase saat benih terendam (Kretzschmar et al., 2015).

Benih yang terendam dapat mengalami kerusakan mekanik, kekurangan cahaya matahari, terbatasnya difusi gas, dan rentan terhadap serangan hama penyakit (Setter et al., 1997; Sujinah et al., 2020). Budidaya padi di daerah tadah hujan memerlukan varietas toleran terhadap tingkat oksigen rendah selama berkecambah dan mampu beradaptasi di lahan yang terendam air sehingga penggunaan varietas toleran kondisi rendah oksigen/anaerob selama perkecambahan sangat diperlukan (Hendawy et al., 2017). Varietas yang memiliki toleransi terhadap kondisi anaerob selama fase perkecambahan lebih layak dan mudah diadopsi pada skala besar. Upaya untuk memperoleh galur padi harapan yang toleran pada kondisi anaerobic germination (AG) masih terus dilakukan. Informasi donor yang sangat toleran belum banyak diketahui, serta studi mekanisme fisiologisnya belum banyak dilakukan (Angaji et al., 2010).

Sampai saat ini, belum ada varietas yang dilepas di Indonesia yang memiliki toleransi pada perkecambahan anaerob. Varietas padi sawah yang telah dilepas adalah untuk toleransi rendaman pada fase vegetatif selama 14 hari yaitu Inpari 29 Rendaman dan Inpari 30 Ciherang SUB1 (Nugraha et al., 2017). Gen penyandi rendaman
(SUB1) dan gen penyandi AG $(A G 1)$ memiliki mekanisme toleransi yang berbeda. Gen $A G 1$ mendorong mobilisasi cadangan endosperm untuk meningkatkan perpanjangan koleoptil sehingga keluar menembus kedalaman tanah yang dangkal. Gen SUB1 menyandikan faktor transkripsi yang responsif terhadap etilen $S U B 1$ A-1, yaitu mempertahankan hidup dengan mengurangi katabolisme karbohidrat, untuk meningkatkan pemulihan pada saat rendaman berakhir. Genotipe yang memiliki pyramiding gen $A G 1$ dan SUB1 menunjukkan interaksi negatif, yaitu daya hidup genotipe menurun ketika benih ditanam di bawah air dan dipertahankan di bawah terendam selama 16 hari. Gen $A G 1$ meningkatkan pemanjangan koleoptil sedangkan gen $S U B 1 \mathrm{~A}-1$ mendorong fotoautotrofi sebelum waktunya dan kemudian membatasi pemanjangan tanaman ketika masih di bawah air. Dengan adanya mekanisme toleransi yang berlawanan tersebut, perakitan varietas toleran AG sebaiknya menggunakan strategi yang spesifik (Alam et al., 2020).

Penyebaran varietas Inpari 30 Ciherang SUB1 terus meningkat mencakup 5\% (775.719 ha) dari luas total area sawah di Indonesia (Nugraha dan Sitaresmi, 2018). Fenomena tersebut memperlihatkan bahwa pada saat ini petani memerlukan varietas-varietas padi sawah yang memiliki toleransi terhadap cekaman abiotik seperti rendaman, kondisi anaerob pada fase perkecambahan, dan kekeringan. Keunggulan suatu varietas ditentukan oleh keragaan agronomi (penampilan fenotipik) suatu galur. Keragaan relatif dari karakter kuantitatif pada berbagai genotipe sering bervariasi dari satu lingkungan ke lingkungan lainnya. Varietas yang dapat mempertahankan daya hasil suatu genotipe yang tinggi pada lingkungan yang luas umumnya merupakan genotipe yang dikehendaki dalam program pemuliaan. Penelitian ini bertujuan untuk mengevaluasi toleransi galur-galur padi pada kondisi anaerob saat fase perkecambahan, serta penampilan agronomi galurgalur padi tersebut di lahan sawah tadah hujan.

\section{BAHAN DAN METODE}

\section{Uji Toleransi terhadap Kondisi Anaerob pada Fase Perkecambahan (AG)}

Evaluasi toleransi cekaman kondisi anaerob dilakukan di Rumah Kaca Balai Besar Penelitian Tanaman Padi (BB Padi) pada bulan Februari 2020. Evaluasi dilakukan untuk mengkonfirmasi kembali tingkat toleransi galur-galur yang telah terseleksi pada kondisi AG pada tahap seleksi pemuliaan sebelumnya. Materi tanaman yang digunakan adalah 10 galur harapan padi, (Tabel 1) dan dua varietas pembanding (Inpari 30 Ciherang Sub-1 dan Inpari 39 Tadah Hujan Agritan), serta KHO sebagai cek toleran AG dan IR64 sebagai cek peka AG. Benih yang digunakan untuk evaluasi pada kondisi anaerob harus dipastikan memiliki kualitas dan vigor benih yang baik, agar tidak terjadi kesalahan dalam menyimpulkan galur-galur yang toleran atau peka. Sebelum ditanam, benih di oven pada suhu $30^{\circ} \mathrm{C}$ selama 2 hari untuk mematahkan dormansi. 
Tabel 1. Bahan tanaman pengujian galur-galur toleran AG

\begin{tabular}{lll}
\hline No & \multicolumn{1}{c}{ Galur/varietas } & \multicolumn{1}{c}{ Keterangan (Asal persilangan) } \\
\hline 1 & BP20106c-SKI-3-1-0 & IRGC 1044-29 (GS 6069)/Ciherang \\
2 & IR 83381-B-B-6-1 & Galur introduksi IRRI \\
3 & IR 83383-B-B-129-4 & Galur introduksi IRRI \\
4 & IR 127165-2-61-Ski-0-Ind-19 & Galur introduksi IRRI \\
5 & IR 129336:11-19-Ski-0-Kn-3 & Galur introduksi IRRI \\
6 & IR 129336:11-8-Ski-0-Kn-8 & Galur introduksi IRRI \\
7 & B14366E-KY-3 & TDK 1 Sub-1/Ciherang \\
8 & B14316E-KA-15 & B11844-MR-29-7-1/Inpara 5//Conde \\
9 & B14897E-SKI-9-7-2 & IR64-SUB1/Mahsuri \\
10 & Ciherang AG & IR64-SUB1/IR64-AG1//Ciherang-SUB1 (Toledo et al., 2015) \\
11 & INPARI 30 Ciherang SUB1 & Varietas padi sawah toleran rendaman sesaat (Nugraha et al., 2017; Sasmita et al., \\
& & 2020) \\
12 & Inpari 39 tadah hujan agritan & Varietas padi sawah tadah hujan (Sasmita et al., 2020) \\
\hline
\end{tabular}

Penapisan toleransi cekaman AG dilakukan berdasarkan Angaji et al. (2010). Percobaan menggunakan Rancangan Kelompok Lengkap Teracak dengan 4 ulangan. Sebanyak 20 butir benih tiap-tiap genotipe ditanam pada box berukuran $40 \times 20 \times 10 \mathrm{~cm}$ dengan media tanah sawah (alluvial) dengan ketebalan sekitar $3 \mathrm{~cm}$. Genotipe ditanam ditambah cek peka dan cek toleran pada masing-masing box. Setelah disebar, benih langsung direndam dengan ketinggian air $10 \mathrm{~cm}$ dan dipertahankan sampai 10 hari, kemudian air disurutkan. Respon galur terhadap kondisi AG diamati sehari setelah air disurutkan, terhadap karakter kemampuan hidup benih (\%), panjang tunas dan panjang akar, serta bobot biomassa kering.

Data yang diperoleh dilakukan analisis ragam tunggal. Uji beda nyata nilai tengah dilakukan berdasarkan metode Beda Nyata Terkecil (BNT) dengan tingkat kepercayaan 95\%. Analisis korelasi Pearson dilakukan untuk mengetahui hubungan karakter penciri toleransi AG. Analisis data dilakukan dengan menggunakan perangkat lunak STAR (www.bbi.irri.org).

\section{Evaluasi Penampilan Agronomi di Sawah Tadah Hujan}

Penelitian uji daya hasil dilakukan di dua lokasi sawah tadah hujan Sumedang, Jawa Barat (535 m dpl, dengan koordinat $-6.818,107.94575$ ) dan Pati, Jawa Tengah (27 m dpl, dengan koordinat -6.4552, 111.02904), pada bulan Februari sampai April 2020. Percobaan ini disusun menggunakan Rancangan Kelompok Lengkap Teracak dengan empat ulangan. Materi tanaman adalah 10 galur harapan padi yang telah terseleksi toleransinya terhadap AG pada tahap pemuliaan sebelumnya. Varietas pembanding yang digunakan adalah Inpari 30 Ciherang SUB1 yang toleran rendaman (Septiningsih et al., 2014; Nugraha et al., 2017) dan Inpari 39 Tadah Hujan Agritan (Tabel 1). Masingmasing genotipe ditanam pada ukuran plot $4 \mathrm{~m}$ x $5 \mathrm{~m}$ dengan jarak tanam $25 \mathrm{~cm}$ x $25 \mathrm{~cm}$. Teknik budidaya mengikuti pola tanam petani setempat, yaitu sistem tanam pindah dengan umur bibit 18- 21 hari. Pada pesemaian dilakukan rendaman selama 10 hari untuk 'menciptakan" kondisi cekaman rendaman pada fase perkecambahan. Pengolahan lahan dilakukan dengan pelumpuran. Pengamatan dilakukan terhadap karakter tinggi tanaman, jumlah anakan produktif, umur 50\% berbunga, jumlah gabah isi dan gabah hampa per malai, bobot 1,000 butir, dan hasil gabah kering giling (GKG).

Data yang diperoleh dilakukan analisis ragam tunggal dan ragam gabungan. Analisis ragam gabungan dilakukan dengan menggunakan model acak. Uji beda nyata nilai tengah dilakukan berdasarkan metode Beda Nyata Terkecil (BNT) dengan tingkat kepercayaan 95\%. Analisis data dilakukan dengan menggunakan perangkat lunak STAR (www.bbi.irri.org).

\section{HASIL DAN PEMBAHASAN}

Toleransi Galur-Galur Padi terhadap Anaerobic Germination (AG)

Hasil analisis ragam menunjukkan genotipe berpengaruh nyata pada karakter jumlah tumbuh, persentase tumbuh, panjang akar, panjang tunas, dan bobot biomassa dalam kondisi cekaman AG (Tabel 2). Genotipe 1) BP2010cSKI-3-1-0, 6) IR 129336:11-8-Ski-0-8, Ciherang AG, Inpari 39 dan Inpari 30 menampilkan respon jumlah tumbuh yang rendah, dengan jumlah tumbuh benih masing-masing secara berurutan 5 butir, 5 butir, 7 butir, 2 butir, dan 4 butir (Tabel 2). Genotipe padi mampu memulai perkecambahan tetapi tidak dapat memanjang lebih jauh, disebabkan hambatan dalam menggunakan cadangan energi saat oksigen terbatas (Miro dan Ismail, 2013). 
KHO sebagai cek toleran AG memiliki jumlah tumbuh sebesar 11.55 butir sedangkan IR64 sebagai cek peka memiliki jumlah tumbuh hanya 1.55 butir. Tujuh galur memiliki jumlah tumbuh lebih banyak dari IR64, yaitu IR 83381-B-B-6-1, IR 83383-B-B-129-4, IR 127165-2-61-Ski0-Ind-19, IR 129336:11-19-Ski-0-Kn-3, B14366E-KY-3, B1431E-KA-15 dan B14897E-SKI-9-7-2 (Tabel 2). Galur padi dengan respon jumlah tumbuh baik diduga memiliki kemampuan menggunakan cadangan pati yang disimpan melalui aktivitas amilase dan respirasi anaerob (Adachi et al., 2015).

Toleransi galur padi pada kondisi AG berkorelasi dengan perkecambahan dan kecepatan pertumbuhan koleoptil (Miro et al., 2017). Salah satu karakter terkait toleransi galur padi terhadap AG ialah persentase tumbuh. Persentase tumbuh galur-galur yang diuji berkisar antara 10\% sampai dengan $68.75 \%$ (Tabel 2). Inpari 30 memiliki persentase tumbuh terendah, IR 83381-B-B-6-1 memiliki persentase tumbuh tertinggi. Galur-galur dengan persentase tumbuh lebih dari cek peka IR64 yaitu IR 83381-B-B-6-1 (68.75\%), IR 83383-B-B-129-4 (48.75\%), IR 1271652-61-Ski-0-Ind-19 (42.50\%), IR 129336:11-19-Ski-0Kn-3 (61.25\%), B14366E-KY-3 (43.75\%), B1431E-KA$15(42.50 \%)$ dan B14897E-SKI-9-7-2 (50\%). Varietas cek toleran KHO memiliki persentase sebesar 57.75\%, sedangkan IR64 memiliki persentase tumbuh sebesar $7.75 \%$. Dua galur yang memiliki persentase tumbuh paling tinggi yaitu IR 83381-B-B-6-1 (68.75\%) dan IR 129336:1119-Ski-0-Kn-3 (61.25\%).

Galur padi dengan toleransi AG dapat dilihat berdasarkan kemampuannya menghasilkan akar dan tunas (Illangakoon et al., 2019). Berta dan Ismail (2013) menyatakan bahwa karakter akar seperti panjang akar dapat digunakan untuk menentukan galur yang toleran. Karakter panjang akar tidak berpengaruh nyata, berkisar antara 2.27$5.11 \mathrm{~cm}$. Panjang akar KHO ialah $3.76 \mathrm{~cm}$, sedangkan panjang akar IR64 ialah $2.46 \mathrm{~cm}$ (Tabel 2). KHO memiliki tunas paling panjang $(18.66 \mathrm{~cm})$, dan IR 64 sebagai cek peka memiliki tunas paling pendek $(2.92 \mathrm{~cm})$. Galur-galur yang diuji memiliki panjang tunas lebih pendek daripada $\mathrm{KHO}$, kecuali galur IR 83381-B-B-6-1 (12.85 cm) yang setara dengan KHO. Genotipe yang memiliki tunas paling pendek adalah Inpari $30(3.42 \mathrm{~cm})$, dan paling panjang yaitu galur IR 83381-B-B-6-1 (12.85 cm).

Karakter bobot biomassa galur-galur yang diuji berkisar antara $0.0461 \mathrm{~g}$ (Ciherang AG) sampai dengan 0.2815 g (IR 83381-B-B-6-1). Ciherang AG merupakan galur toleran AG, diperoleh dari proses pemuliaan Marker Assisted Backcrossing antara Ciherang dengan IR64AG1 (Toledo et al., 2015). IR64-AG1 dihasilkan dari penyisipan gen toleran $A G 1$ dari landrace Khao Hlan On, yang memiliki QTL toleran AG, qAG-9-2 (Angaji et al., 2010). Dari performa daya hasil di dua lokasi, Ciherang AG memiliki rata-rata hasil GKG 4.77 ton $\mathrm{ha}^{-1}$, tidak berbeda

Tabel 2. Jumlah tumbuh, persentase tumbuh, panjang akar, panjang tunas dan bobot biomassa genotipe padi pada kondisi anaerobic germination

\begin{tabular}{llccrrc}
\hline No & \multicolumn{1}{c}{ Genotipe } & JT (butir) & PT $(\%)$ & PA $(\mathrm{cm})$ & PTN $(\mathrm{cm})$ & BB $(\mathrm{g})$ \\
\hline 1 & BP2010c-SKI-3-1-0 & 4.75 & 23.75 & 4.14 & 10.06 & 0.135 \\
2 & IR 83381-B-B-6-1 & 13.75 & 68.75 & 5.11 & 12.85 & 0.282 \\
3 & IR 83383-B-B-129-4 & 9.75 & 48.75 & 3.53 & 7.72 & 0.101 \\
4 & IR 127165-2-61-Ski-0-Ind-19 & 8.50 & 42.50 & 4.21 & 9.19 & 0.084 \\
5 & IR 129336:11-19-Ski-0-Kn-3 & 12.25 & 61.25 & 4.10 & 10.37 & 0.178 \\
6 & IR 129336:11-8-Ski-0-8 & 5.00 & 25.00 & 3.60 & 7.04 & 0.066 \\
7 & B14366E-KY-3 & 8.75 & 43.75 & 4.17 & 7.87 & 0.081 \\
8 & B1431E-KA-15 & 8.50 & 42.50 & 3.83 & 7.58 & 0.054 \\
9 & B14897E-SKI-9-7-2 & 10.00 & 50.00 & 4.55 & 10.13 & 0.093 \\
10 & Ciherang AG & 7.00 & 35.00 & 3.28 & 7.10 & 0.046 \\
11 & Inpari 30 Ciherang SUB1 & 2.00 & 10.00 & 3.35 & 3.42 & 0.005 \\
12 & Inpari 39 Tadah Hujan Agritan & 3.75 & 18.75 & 2.27 & 5.13 & 0.052 \\
13 & KHO & 11.55 & 57.75 & 3.76 & 18.66 & 0.024 \\
14 & IR64 & 1.55 & 7.75 & 2.46 & 2.92 & 0.027 \\
\hline & KK (\%) & 39.41 & 41.07 & 49.69 & 47.52 & 91.75 \\
& BNT (5\%) & 5.52 & 21.11 & tn & 5.83 & 0.090 \\
\hline & Uji kehomogenan ragam - Bartlett $\left(\chi^{2}\right)$ & $28.42^{* *}$ & $17.34 \mathrm{tn}$ & $6.80 \mathrm{tn}$ & $6.85 \mathrm{tn}$ & $24.200^{*}$ \\
& Uji kenormalan data - Shapiro-Wilk & 0.9909 tn & 0.9939 tn & $0.9744 \mathrm{tn}$ & $0.9868 \mathrm{tn}$ & 0.967 \\
\hline
\end{tabular}

Keterangan: JT = Jumlah tumbuh (analisis ragam menggunakan data transformasi); PT = persentase tumbuh (analisis ragam menggunakan data transformasi); PA = panjang akar; $\mathrm{PTN}=$ panjang tunas; $\mathrm{BB}=$ bobot biomassa 
nyata dengan Inpari 30 (5.26 ton $\left.\mathrm{ha}^{-1}\right)$ dan Inpari 39 (5.52 ton $\mathrm{ha}^{-1}$ ) (Tabel 2). Tiga galur memiliki bobot biomassa lebih tinggi dari dua varietas cek, yaitu BP2010c-SKI3-1-0 (0.1345 g), IR 83381-B-B-6-1(0.2815 g), dan IR 129336:11-19-Ski-0-Kn-3 (0.1777 g) (Tabel 2). Rachmawati dan Retnaningrum (2013) melaporkan tanaman dengan perlakuan penggenangan mempunyai berat kering lebih tinggi daripada tanpa penggenangan. Biomassa tanaman mencerminkan hasil fotosintesis bersih (net photosynthesis) yang terkait dengan ketersediaan nutrien yang dapat diserap oleh tanaman. Pada kondisi genangan, kandungan NO3 menjadi lebih tinggi dan tersedia, selanjutnya digunakan tanaman padi untuk pertumbuhannya (Barker dan Pilbeam, 2007).

Analisis korelasi antar karakter terkait respon tanaman terhadap cekaman AG dilakukan untuk menentukan toleransi galur-galur yang diuji. Persentase tumbuh berkorelasi nyata dan positif dengan panjang akar $(\mathrm{r}=0.744)$, panjang tunas $(\mathrm{r}=0.778)$, dan biomassa tanaman $(\mathrm{r}=0.628)$. Panjang akar berkorelasi nyata dan positif dengan panjang tunas $(\mathrm{r}=0.609)$ dan bobot biomassa $(\mathrm{r}=0.684)$, sedangkan panjang tunas memiliki hubungan yang lemah dengan biomassa dengan nilai $r=0.363$ (Tabel 3). Meskipun demikian, panjang tunas merupakan salah satu karakter penting dalam kriteria seleksi toleransi terhadap AG (Ismail et al., 2012; Illangakoon et al., 2019). Toleransi genotipe diseleksi berdasarkan persentase tumbuh tinggi, tunas yang panjang, atau biomassa yang berat. Berdasarkan ketiga kiteria tersebut, galur IR 83381B-B-6-1, IR 129336:11-19-Ski-0-Kn-3, dan B14897E-SKI9-7-2 diidentifikasi sebagai genotipe toleran AG.

\section{Penampilan Agronomi Galur-galur Padi di Dua Lokasi Sawah Tadah Hujan}

Hasil analisis ragam masing-masing lokasi menunjukkan perbedaan nyata pada semua karakter agronomi yang diamati, kecuali jumlah anakan produktif galur-galur yang diuji di Sumedang tidak berbeda nyata. Analisis ragam gabungan dua lokasi menunjukkan bahwa terdapat interaksi genotipe $\mathrm{x}$ lingkungan pada karakter tinggi tanaman, jumlah anakan, jumlah gabah isi per malai, bobot 1,000 butir, dan hasil gabah kering giling. Genotipe berpengaruh nyata pada karakter tinggi tanaman, jumlah gabah hampa, dan bobot 1,000 butir (Tabel 4). Karakter

Tabel 3. Korelasi antar karakter terkait toleransi cekaman anaerobic germination pada tanaman padi

\begin{tabular}{|c|c|c|c|c|}
\hline & PT & PA & PTN & $\mathrm{BB}$ \\
\hline PT & & $0.744 * *$ & $0.778 * *$ & $0.628 *$ \\
\hline PA & & & $0.609 *$ & $0.684 * *$ \\
\hline PTN & & & & $0.363 \mathrm{tn}$ \\
\hline
\end{tabular}

Keterangan: $\mathrm{PT}=$ persentase tumbuh; $\mathrm{PA}=$ panjang akar; $\mathrm{PTN}=$ panjang tunas; $\mathrm{BB}=$ bobot biomassa; $* *$ berkorelasi nyata pada $\mathrm{p}<0.01 ; * *$ berkorelasi nyata pada $\mathrm{p}$ $<0.05 ; \mathrm{tn}=$ tidak berkorelasi nyata tinggi tanaman, jumlah anakan produktif, jumlah gabah isi dan gabah hampa, bobot 1,000 butir, dan hasil GKG merupakan karakter kuantitatif sehingga selain dipengaruhi oleh genotipe, ekspresi karakter-karakter tersebut juga banyak dipengaruhi oleh lingkungan dan interaksi genotipe x lingkungan (Sitaresmi et al., 2013; 2016; 2019).

Tinggi tanaman merupakan salah satu karakter yang menjadi preferensi petani. Tanaman yang terlalu tinggi akan rentan terhadap kerebahan. Tanaman yang terlalu pendek akan menyulitkan pemotongan pada saat panen. Rata-rata tinggi tanaman galur-galur yang diuji berkisar antara 85-118 $\mathrm{cm}$ (Tabel 5). Tipe tanaman ideal yang disukai petani adalah setara dengan Ciherang, atau dalam set ini adalah Inpari 30 karena varietas ini merupakan turunan esensial dari Ciherang yang telah disisipi gen SUB1 (toleran rendaman) dan telah menempati empat besar dari luas area tanam padi di Indonesia (Nugraha dan Sitaresmi, 2018). Varietas pembanding Inpari 39 memiliki rata-rata tinggi tanaman tidak berbeda nyata dengan Inpari 30. Galur-galur yang diuji secara umum memiliki tinggi tanaman setara dengan Inpari 30 dan Inpari 39, kecuali galur IR 129336:11-8-Ski0-Kn-8 yang berpostur pendek dan B14897E-SKI-9-7-2 yang berpostur cukup tinggi. Tinggi tanaman merupakan salah satu karakter penting yang dipertimbangkan dalam pemilihan calon varietas yang akan diusulkan untuk dilepas.

Rata-rata jumlah anakan produktif berkisar antara 1520 batang per rumpun. Semua galur yang diuji memiliki jumlah anakan setara dengan Inpari 30 dan Inpari 39. Ratarata umur $50 \%$ berbunga di Pati lebih genjah daripada di Sumedang, dikarenakan Sumedang (535 m dpl) memiliki elevasi lebih tinggi daripada Pati (27 m dpl). Setiap kenaikan $100 \mathrm{~m}$ dari permukaan laut maka suhu akan turun $1{ }^{\circ} \mathrm{C}$. Penurunan suhu akan memperlambat waktu pembungaan (Sanghera et al., 2011; Gunarsih et al., 2016; Purwanto et al., 2018; Yamuangmorn et al., 2020). Rata-rata bobot 1,000 butir berkisar antara 25-30 g. Galur IR 129336:11-19-Ski-0Kn-3, B14316E-KA-15, dan B14897E-SKI-9-7-2 memiliki ukuran biji lebih besar dengan bobot 1,000 butir \pm 30 gram. Jumlah gabah isi per malai berkisar antara 75-92 butir per malai. Galur-galur yang diuji memiliki jumlah gabah isi setara dengan Inpari 30 dan Inpari 39 (Tabel 5).

Rata-rata hasil gabah kering di lokasi Pati setara dengan lokasi Sumedang. Varietas pembanding Inpari 30 memiliki hasil GKG setara dengan Inpari 39. Galur-galur yang memiliki hasil GKG lebih tinggi daripada Inpari 39 di lokasi Pati yaitu galur IR 83381-B-B-6-1 (6 ton ha-1), IR 83383-B-B-129-4 (5.74 ton ha-1), IR 129336:11-19-Ski-0Kn-3 (5.36 ton ha-1), dan 8) B14316E-KA-15 (5.56 ton ha-1). Keragaan hasil GKG di lokasi Sumedang berkisar antara 3.99-5.19 ton $\mathrm{ha}^{-1}$. Varietas pembanding Inpari 39 (6.21 ton $\left.\mathrm{ha}^{-1}\right)$ memiliki hasil tidak berbeda nyata dengan Inpari 30 (5.66 ton $\mathrm{ha}^{-1}$ ). Hasil GKG galur yang diuji tidak ada yang lebih tinggi dari Inpari 30 dan Inpari 39. Rata-rata hasil GKG dua lokasi menunjukkan kisaran 3.88-6.04 ton ha $^{-1}$, dengan hasil GKG Inpari 39 sebesar 5.52 ton ha ${ }^{-1}$ dan Inpari 30 sebesar 5.26 ton $\mathrm{ha}^{-1}$. Semua galur yang diuji memiliki 
Tabel 4. Analisis ragam karakter agronomi galur-galur padi sawah tadah hujan

\begin{tabular}{|c|c|c|c|c|c|c|c|}
\hline \multirow{2}{*}{ Sumber keragaman } & \multirow{2}{*}{$\mathrm{db}$} & \multicolumn{2}{|c|}{ Tinggi tanaman } & \multicolumn{2}{|c|}{ Jumlah anakan } & \multicolumn{2}{|c|}{ Jumlah gabah isi } \\
\hline & & KT & $\operatorname{Pr}>F$ & KT & $\operatorname{Pr}>F$ & KT & $\operatorname{Pr}>F$ \\
\hline Lokasi & 1 & $2,166.00$ & 0.00 & 10.67 & 0.27 & $12,421.50$ & $<.0001$ \\
\hline Ulangan / Lokasi & 6 & 26.31 & 0.11 & 7.28 & 0.28 & 45.99 & 0.84 \\
\hline Genotipe & 11 & 481.78 & 0.00 & 13.89 & 0.46 & 482.91 & 0.06 \\
\hline Genotipe*Lokasi & 11 & 50.34 & 0.00 & 13.03 & 0.02 & 185.00 & 0.07 \\
\hline Galat & 66 & 14.68 & & 5.72 & & 101.64 & \\
\hline Total terkoreksi & 95 & & & & & & \\
\hline \multirow{2}{*}{ Sumber keragaman } & \multirow{2}{*}{$\mathrm{db}$} & \multicolumn{2}{|c|}{ Jumlah gabah hampa } & \multicolumn{2}{|c|}{ Bobot 1,000 butir } & \multicolumn{2}{|c|}{ Hasil GKG } \\
\hline & & KT & $\operatorname{Pr}>F$ & KT & $\operatorname{Pr}>F$ & KT & $\operatorname{Pr}>F$ \\
\hline Lokasi & 1 & $35,458.59$ & $<.0001$ & 0.15 & 0.81 & 0.02 & 0.92 \\
\hline Ulangan / Lokasi & 6 & 299.29 & 0.01 & 2.33 & 0.06 & 1.96 & 0.01 \\
\hline Genotipe & 11 & 445.68 & 0.02 & 31.12 & 0.00 & 2.25 & 0.38 \\
\hline Genotipe*Lokasi & 11 & 127.00 & 0.18 & 3.24 & 0.00 & 1.86 & 0.00 \\
\hline Galat & 66 & 88.03 & & 1.08 & & 0.62 & \\
\hline Total terkoreksi & 95 & & & & & & \\
\hline
\end{tabular}

hasil setara dengan kedua varietas pembanding. Meskipun demikian, terdapat dua galur yang memiliki tren hasil GKG konsisten cukup tinggi baik di lokasi Pati, Sumedang, dan rata-rata kedua lokasi, yaitu galur IR 129336:11-19-Ski-0Kn-3 dan B14316E-KA-15 (Tabel 5). Meskipun demikian, daya hasil galur IR 83381-B-B-6-1, IR 129336:11-19Ski-0-Kn-3, B1431E-KA-15, B14897E-SKI-9-7-2 masih perlu dilihat pada uji adaptasi lebih lanjut untuk pelepasan varietas.

Dari pengujian toleransi $\mathrm{AG}$ di rumah kaca teridentifikasi tiga galur (IR 83381-B-B-6-1, IR 129336:1119-Ski-0-Kn-3, dan B14897E-SKI-9-7-2). Demikian untuk rata-rata hasil GKG, galur IR 83381-B-B-6-1 (4.89 ton ha $^{-1}$ ), IR 129336:11-19-Ski-0-Kn-3 (5.61 ton ha ${ }^{-1}$ ), dan

Tabel 5. Rata-rata karakter agronomi galur-galur padi di dua lokasi sawah tadah hujan

\begin{tabular}{|c|c|c|c|c|c|c|c|c|c|c|c|c|c|}
\hline \multirow{2}{*}{ No } & \multirow{2}{*}{ Galur/Varietas } & \multicolumn{3}{|c|}{$\begin{array}{l}\text { Tinggi tanaman } \\
(\mathrm{cm})\end{array}$} & \multicolumn{3}{|c|}{ Jumlah anakan } & \multicolumn{3}{|c|}{$\begin{array}{c}\text { Waktu berbunga } \\
\text { (HSS) }\end{array}$} & \multicolumn{3}{|c|}{$\begin{array}{c}\mathrm{B} 1,000 \\
(\mathrm{~g})\end{array}$} \\
\hline & & A & B & $\begin{array}{c}\text { Rata- } \\
\text { rata }\end{array}$ & A & B & $\begin{array}{l}\text { Rata- } \\
\text { rata }\end{array}$ & A & $\mathrm{B}$ & $\begin{array}{c}\text { Rata- } \\
\text { rata }\end{array}$ & A & $\mathrm{B}$ & $\begin{array}{c}\text { Rata- } \\
\text { rata }\end{array}$ \\
\hline 1 & BP20106c-SKI-3-1-0 & 98 & 92 & 95 & 23 & 17 & 20 & 54 & 85 & 70 & 25.5 & 25 & 25.2 \\
\hline 2 & IR 83381-B-B-6-1 & 109 & 90 & 100 & 17 & 17 & 17 & 52 & 84 & 68 & 25.6 & 24.1 & 24.8 \\
\hline 3 & IR 83383-B-B-129-4 & 110 & 99 & 104 & 18 & 20 & 19 & 55 & 85 & 70 & 26.6 & 25.6 & 26.1 \\
\hline 4 & IR 127165-2-61-Ski-0-Ind-19 & 105 & 93 & 99 & 18 & 20 & 19 & 57 & 88 & 73 & 26.5 & 28.0 & 27.2 \\
\hline 5 & IR 129336:11-19-Ski-0-Kn-3 & 103 & 95 & 99 & 18 & 16 & 17 & 61 & 89 & 75 & 28.7 & 31.4 & 30.0 \\
\hline 6 & IR 129336:11-8-Ski-0-Kn-8 & 93 & 77 & 85 & 19 & 22 & 20 & 53 & 87 & 70 & 27.1 & 25.9 & 26.5 \\
\hline 7 & B14366E-KY-3 & 103 & 99 & 101 & 19 & 18 & 18 & 55 & 88 & 72 & 28.3 & 27.5 & 27.9 \\
\hline 8 & B14316E-KA-15 & 113 & 102 & 107 & 18 & 17 & 18 & 60 & 87 & 73 & 29.6 & 31.1 & 30.4 \\
\hline 9 & B14897E-SKI-9-7-2 & 126 & 111 & 118 & 15 & 16 & 15 & 58 & 83 & 70 & 30.9 & 30.4 & 30.6 \\
\hline 10 & Ciherang AG & 105 & 99 & 102 & 18 & 17 & 17 & 57 & 87 & 72 & 26.8 & 26.7 & 26.8 \\
\hline 11 & INPARI 30 Ciherang SUB1 & 102 & 98 & 100 & 18 & 16 & 17 & 60 & 92 & 76 & 27.7 & 26.9 & 27.3 \\
\hline \multirow[t]{4}{*}{12} & INPARI 39 tadah hujan Agritan & 103 & 100 & 102 & 18 & 17 & 18 & 58 & 91 & 75 & 26.2 & 25.9 & 26.1 \\
\hline & Rata-rata $(\mathrm{cm})$ & 106 & 96 & 101 & 18 & 18 & 18 & 57 & 87 & 72 & 27.5 & 27.4 & 27.4 \\
\hline & BNT $(5 \%)$ & 4.32 & 6.49 & 9.18 & 1.88 & tn & tn & & & & 1.59 & 1.39 & 1.04 \\
\hline & KK $(\%)$ & 2.80 & 4.70 & 3.80 & 7.20 & 17.70 & 13.30 & & & & 4.00 & 3.50 & 3.79 \\
\hline
\end{tabular}

Keterangan: Bunga $=$ Umur 50\% berbunga; $\mathrm{B} 1,000=$ Bobot 1,000 butir; $\mathrm{A}=$ Pati; $\mathrm{B}=$ Sumedang; tn $=$ tidak nyata 
Tabel 5. Rata-rata karakter agronomi galur-galur padi di dua lokasi sawah tadah hujan (lanjutan)

\begin{tabular}{llrrrrrrrrr}
\hline \multirow{2}{*}{ No } & \multirow{2}{*}{ Galur/Varietas } & \multicolumn{3}{c}{ Jumlah gabah isi } & \multicolumn{3}{c}{ Jumlah gabah hampa } & \multicolumn{3}{c}{ Hasil (ton ha ${ }^{-1}$ ) } \\
\cline { 3 - 10 } & A & B & Rata-rata & A & B & Rata-rata & A & B & Rata-rata \\
\hline 1 & BP20106c-SKI-3-1-0 & 80 & 74 & 77 & 14 & 54 & 34 & 5.32 & 4.95 & 5.14 \\
2 & IR 83381-B-B-6-1 & 114 & 70 & 92 & 17 & 56 & 37 & 6.00 & 3.79 & 4.89 \\
3 & IR 83383-B-B-129-4 & 92 & 69 & 80 & 18 & 59 & 38 & 5.74 & 5.19 & 5.47 \\
4 & IR 127165-2-61-Ski-0-Ind-19 & 76 & 56 & 66 & 21 & 54 & 37 & 5.29 & 4.74 & 5.01 \\
5 & IR 129336:11-19-Ski-0-Kn-3 & 94 & 67 & 80 & 23 & 58 & 41 & 5.36 & 5.86 & 5.61 \\
6 & IR 129336:11-8-Ski-0-Kn-8 & 81 & 49 & 65 & 17 & 44 & 31 & 3.78 & 3.99 & 3.88 \\
7 & B14366E-KY-3 & 95 & 78 & 87 & 20 & 65 & 43 & 4.87 & 5.48 & 5.17 \\
8 & B14316E-KA-15 & 90 & 61 & 76 & 29 & 75 & 52 & 5.56 & 6.53 & 6.04 \\
9 & B14897E-SKI-9-7-2 & 91 & 75 & 83 & 26 & 78 & 52 & 5.01 & 5.19 & 5.10 \\
10 & Ciherang AG & 90 & 75 & 82 & 16 & 60 & 38 & 5.10 & 4.45 & 4.77 \\
11 & INPARI 30 Ciherang SUB1 & 93 & 68 & 80 & 16 & 42 & 29 & 4.86 & 5.66 & 5.26 \\
12 & INPARI 39 tadah hujan Agritan & 84 & 66 & 75 & 14 & 48 & 31 & 4.83 & 6.21 & 5.52 \\
\hline & Rata-rata & 90 & 67 & 79 & 19 & 58 & 38 & 5.14 & 5.17 & 5.16 \\
& BNT (5\%) & 10.9 & 15.4 & 12.8 & 19.1 & 22.1 & 24.4 & 6.61 & 20.50 & 15.27 \\
& KK (\%) & 14.0 & 15.0 & tn & 5.0 & 18.0 & 9.0 & 0.49 & 1.52 & tn \\
\hline
\end{tabular}

Keterangan: $\mathrm{A}=$ Pati; $\mathrm{B}=$ Sumedang; $\mathrm{tn}=$ tidak nyata

B14897E-SKI-9-7-2 (5.10 ton ha $\left.^{-1}\right)$ memiliki hasil GKG relatif konsisten di dua lokasi dan tidak berbeda nyata dengan varietas pembanding terbaik Inpari 39 Tadah Hujan Agritan. Galur B1431E-KA-15 memiliki rata-rata GKG (6.04 ton $\mathrm{ha}^{-1}$ ), tetapi sifat-sifat terkait toleransi AG masih berada di bawah nilai ketiga galur tersebut.

\section{KESIMPULAN}

Toleransi tanaman padi terhadap kondisi AG dapat diidentifikasi berdasarkan karakter persentase tumbuh (daya pulih), panjang tunas, panjang akar, dan biomassa. Karakter-karakter tersebut saling memiliki korelasi yang positif. Galur IR 83381-B-B-6-1, IR 129336:11-19-Ski0-Kn-3 dan B14897E-SKI-9-7-2 memiliki toleransi AG lebih baik daripada varietas Inpari 30 (Ciherang Sub-1) dan Inpari 39. Dari rata-rata penampilan agronomi di sawah tadah hujan, teridentifikasi galur IR 129336:11-19-Ski-0Kn-3 (5.61 ton ha ${ }^{-1}$ ) dan B14316E-KA-15 (6.04 ton ha-1) memiliki rata-rata GKG setara dengan Inpari 30 dan Inpari 39 , serta konsisten cukup tinggi di dua lokasi. IR 83381B-B-6-1 memiliki hasil 4.89 ton ha $^{-1}$, tidak berbeda nyata dengan kedua varietas pembanding. Penampilan daya hasil dan toleransi ketiga galur tersebut perlu dievaluasi lebih lanjut melalui uji multi lokasi.

\section{UCAPAN TERIMA KASIH}

Penelitian ini dibiayai oleh DIPA Balai Besar Penelitian Tanaman Padi Tahun Anggaran 2020. Kontribusi penulis dalam penulisan makalah ini adalah sebagai berikut: TS (melakukan percobaan di lapang, analisis data, dan menulis makalah); NK (melakukan percobaan di rumah kaca, analisis data, dan menulis makalah); AFVY (melakukan perbanyakan benih materi penelitian); IAR, US, NFS (memberi masukan terhadap penulisan); YN (penanggung jawab penelitian dan memberi masukan terhadap penulisan).

\section{DAFTAR PUSTAKA}

Adachi, Y., M. Sugiyama, J. Sakagami, A. Fukuda, M. Ohe, H. Watanabe. 2015. Seed germination and coleoptile growth of new rice lines adapted to hypoxic conditions. Plant Prod. Sci. 18:471-475.

Angaji, S.A., E.M. Septiningsih, D.J. Mackill., A.M. Ismail. 2010. QTLs associated with tolerance of flooding during germination in rice (Oryza sativa L.). Euphytica 172:159-168. Doi:10.1007/s10681009-0014-5.

Alam, R., M. Hummel, E. Yeung, A.M. Locke, J.C.I. Ignacio, M.D. Baltazar, Z. Jia, A.M. Ismail, E.M. Septiningsih, J. Bailey-Serres. 2020. Flood resilience loci SUBMERGENCE 1 and ANAEROBIC GERMINATION 1 interact in seedlings established underwater. Plant Direct 1-19. Doi:10.1002/ pld3.240.

Barker, A.V., D.J. Pilbeam. 2007. Handbook of Plant Nutrition. Boca Raton London New York.CRC Press. Taylor \& Francis Group, NY. 
Berta, M., A.M. Ismail. 2013. Tolerance of anaerobic conditions caused by flooding during germination and early growth in rice (Oryza sativa L.). Front. Plant Sci. 4:269-276.

Bordoloi, D., D. Sarma. 2018. Aerobic versus anaerobic germination performance of selected rice (Oryza sativa L.) genotypes with or without submergence tolerance. J. Exp. Biol. Agric. Sci. 6:947-958. Doi:10 $.18006 / 2018.6(6) .947 .958$.

Chamara, B.S., B. Marambe, V. Kumar, A.M. Ismail, E.M. Septiningsih, B.S. Chauhan. 2018. Optimizing sowing and flooding depth for anaerobic germinationtolerant genotypes to enhance crop establishment, early growth, and weed management in dry-seeded rice (Oryza sativa L.). Front. Plant Sci. 8:1-15. Doi:10.3389/fpls.2018.01654.

Gunarsih, C., Nafisah, T. Sitaresmi. 2016. Pembentukan varietas padi sawah dataran tinggi toleran cekaman suhu rendah. Iptek Tanaman Pangan 11:107-118.

Hamid, A. 2005. Penentuan jumlah benih padi sebar langsung untuk menekan pertumbuhan gulma. Bul. Teknik Pert. 9:1-3.

Hendawy, S.E.E., C. Sone C, O. Ito, J.I. Sakagami. 2011. Evaluation of germination ability in rice seeds under anaerobic conditions by cluster analysis. Res. J. Seed Sci. 4:82-93.

Hill, J.E., D.E. Bayer, S. Bocchi, W.S. Clampett. 1991. Direct seeded rice in the temperate climates of Australia, Italy, and the United States. In Direct Seeded Flooded Rice in the Tropics: Selected Papers from the International Rice Research Conference, 27-31 August 1990, Seoul, Korea (p. 91). Int. Rice Res. Inst.

Illangakoon, T.K., B. Marambe, R.S.K. Keerthisena, A.P. Bentota, S. Kulatunge, V. Kumar, A.M Ismail. 2018. Performance of anaerobic germination-tolerant rice varieties in direct seeding: effects on stand establishment, weed growth and yield under different seeding rates. Trop. Agric. Res. 29:276-287.

Illangakoon, T.K., B. Marambe, R.S.K. Keerthisena, V. Kumar. 2019. Importance of anaerobic seed germination and seedling development in directseeded rice with special reference to Sri Lanka. Sri Lanka J. Food Agric. 5:47-57.

Ismail, A.M., E.S. Ella, G.V. Vergara, D.J. Mackill. 2009. Mechanisms associated with tolerance to flooding during germination and early seedling growth in rice (Oryza sativa). Ann. Bot. 103:197-209. Doi:10.1093/ aob/mon211.
Ismail, A.M., D.E. Johnson, E.S. Ella, G.V. Vergara, A.M. Baltazar. 2012. Adaptation to flooding during emergence and seedling growth in rice and weeds, and implications for crop establishment. AoB PLANTS. Doi:10.1093/aobpla/pls019.

Kretzschmar, T., M.A.F Pelayo, K.R. Trijatmiko, L.F.M Gabunada, R. Alam, R. Jimenez, M.S. Mendioro, I.H. Slamet-Loedin, N. Sreenivasulu, J. BaileySerres, A. M. Ismail, D.J. Mackill. 2015. A trehalose6-phosphate phosphatase enhances anaerobic germination tolerance in rice. Nature Plants 1: 15124.

Miro, B., A.M. Ismail. 2013. Tolerance of anaerobic conditions caused by flooding during germination and early growth in rice (Oryza sativa L.). Front Plant Sci. Doi:10.3389/fpls.2013.00269.

Miro, B., T. Longkumar, F.D. Entila, A. Kohli, A.M. Ismail. 2017. Rice seed germination underwater: morphophysiological responses and the bases of differential expression of alcoholic fermentation enzymes. Front. Plant Sci. 8:1857. Doi:10.3389/fpls.2017.01857.

Nugraha, Y., N. Hidayatun, Trisnaningsih, D. Yuliani, S.D. Ardhiyanti, T.S. Kadir. 2017. Phenotypic performance of Ciherang sub1 near isogenic line as an adaptive variety for flooding conditions. Indonesian J. Agric. Sci. 18:7-16.

Nugraha, Y., T. Sitaresmi. 2018. Upaya peningkatan produktivitas padi dari sisi pedekatan genetik. Iptek. Tanaman Pangan 13:1-10.

Nugraha, Y., G.V. Vergara, D.J. Mackill, A.M. 2013. Response of Sub1 introgression lines of rice to various flooding conditions. Indonesian J. Agric. Sci. 14:15-26. Doi:10.21082/ijas.v14n1.2013.p15-26.

Purwanto, E., W. Hidayati, Nandariyah. 2018. The yield and quality of black rice varieties in different altitude. IOP Conf. Series: Earth and Environmental Science 142:1-7. Doi:10.1088/1755-1315/142/1/012037.

Rachmawati, D., E. Retnaningrum Pengaruh tinggi dan lama penggenangan terhadap pertumbuhan padi kultivar sintanur dan dinamika populasi rhizobakteri pemfiksasi nitrogen non simbiosis. Bionatura-J. Ilmu-ilmu Hayati dan Fisik 15:117-125.

Sasmita, P., Suprihanto, Y. Nugraha, I. Hasmi, Satoto, I.A. Rumanti, Z. Susanti, B. Kusbiantoro, Rahmini, A. Hairmansis, T. Sitaresmi, Suharna, M. Norvyani, D. Arismiati. 2020. Deskripsi Varietas Unggul Padi. Badan Penelitian dan Pengembangan Pertanian. Kementerian Pertanian. 
Septiningsih, E.M., J.C.L. Ignacio, P.M.D. Sendon, D.L. Sanchez, A.M. Ismail, D.J. Mackill 2013. QTL mapping and confirmation for tolerance of anaerobic conditions during germination derived from the rice landrace Ma-Zhan Red. Theor. Appl. Genet. 126:1357-1366. Doi:10.1007/s0012 2-013-2057-1.

Septiningsih, E.M., N. Hidayatun, D.L. Sanchez, Y. Nugraha, J. Carandang, A.M. Pamplona, B.C.Y. Collard, A.M. Ismail, D.J. Mackill. 2014. Accelerating the development of new submergence tolerant rice varieties: the case of Ciherang-Sub1 and PSB Rc18Sub1. Euphytica 202:259-268.

Sanghera, G.S., S.H. Wani, W. Hussain, N.B. Singh. 2011. Engineering cold stress tolerance in crop plants. Curr. Genom. 12:30-43.

Sitaresmi, T., C. Gunarsih, Nafisah, Y. Nugraha, B. Abdullah, I. Hanarida, H. Aswidinnoor, I.G.P. Muliarta, A.A. Daradjat, dan B. Suprihatno. 2016. Interaksi genotipe $\mathrm{x}$ lingkungan untuk hasil gabah padi sawah. J. Penelitian Pertanian Tanaman Pangan 35:89-98.

Sitaresmi, T., Nafisah, C. Gunarsih, A.A. Daradjat. 2012. Analisis stabilitas hasil gabah galur-galur padi melalui pendekatan parametrik dan nonparametrik. J. Penelitian Pertanian Tanaman Pangan 31:1-8.

Sitaresmi, T., W.B. Suwarno, I.A. Rumanti, S.W. Ardie, H. Aswidinnoor. 2019. Parameters and secondary characters for selection of tolerance rice varieties under stagnant flooding condition. Agrivita J. Agric. Sci. 41:372-384.

Sujinah, N. Agustiani, I.A. Rumanti. 2020. Daya adaptasi padi pada kondisi rendaman stagnan. Penelitian Pertanian Tanaman Pangan 4:17-26.

Toledo, A.M.U., J.C.I.Ignacio, C. Casal Jr., Z.J. Gonzaga, M.S. Mendioro, E.M. Septiningsih. 2015. Development of improved Ciherang-Subl having tolerance to anaerobic germination conditions. Plant Breed. Biotech. 3:77-87. Doi:10.9787/ PBB.2015.3.2.077.

Tuong, T.P., A.K. Singh, J.D.L.C. Siopongco, L.J. Wade. 2000. Constraints to high yield of dry-seeded rice in the rainy season of a humid tropic environment. Plant Prod. Sci. 3:164-172.

Yamuangmorn, S., S. Jumrus, S. Jamjod, N. Yimyam, C.Promu-Thai. 2021. Stabilizing grain yield and nutrition quality in purple rice varieties by management of planting elevation and storage conditions. Agronomy 11-83. Doi:10.3390/agronomy11010083.

Yullianida, Suwarno, S.W. Ardie, H. Aswidinnoor. 2014. Uji cepat toleransi tanaman padi terhadap cekaman rendaman pada fase vegetatif. J. Agron. Indonesia 42:89-95. 